\title{
メースエキスおよび卵白リゾチーム 含有ガムの臨床効果について
}

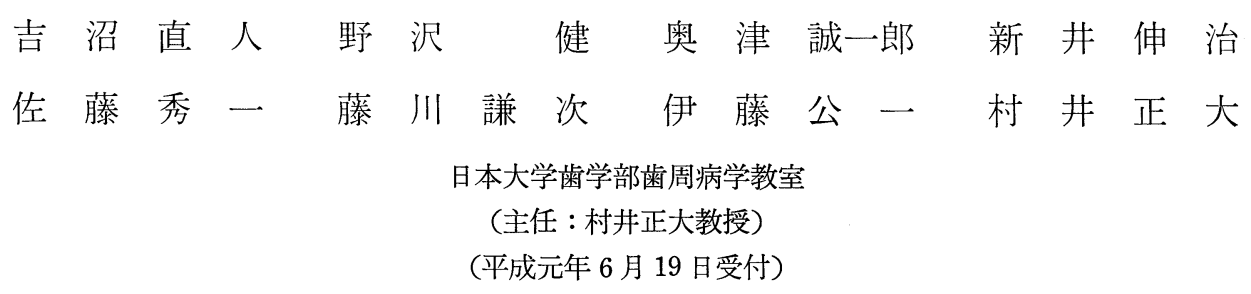

\section{The Clinical Effects of Chewing Gum Containing Egg-White Lysozyme and Mace Extract}

\author{
Naoto YOSHINUMA, Takeshi NOZAWA, Seiichirou OKUTSU, Shinji ARAI, \\ Shuichi SATOH, Kenji FUJIKAWA, Koichi ITO and Seidai MURAI \\ Department of Periodontology Nihon University School of Dentisitry
}

(Director : Prof. Seidai MURAI)

The purpose of this study was to evaluate the clinical effect of mace extract and egg-white lysozyme in two brands of chewing gum on gingival condition. Ever since mace extract containing dihydroguaiaretic acid was reported to inhibit the growth of Streptococcus mutans, plans were devised to include it in commercially available chewing gum.

Before starting this study, two different types of experimental chewing gum containing mace extract or egg-white 1ysozyme were made up. A control was also prepared containing neither agent.

The periodontal condition of 68 patients with gingivitis was determined based on PMA index (PMA), gingival index (GI), gingival bleeding index
(GBI) and plaque scoring system (PSS) and randomly classified into three groups. Each group was instructed to use one or the other of the above type chewing gums after every meal.

The results were as follows :

1. No clinical changes were observed in the control group during this study.

2. Gingival inflammation (PMA, GI, GBI) significantly improved as a result of using the experimental gums.

3. Plaque reduction was found only in the meceextract gum group.

4. No clinical side effects were detected during this study.

Key words : Mace extract, Egg-white lysozyme, Chewing gum, Gingivitis

要旨 : 歯周疾患の予防および治療に対する補助的方法として, チューインガムに薬剤を添加し患者に使用させるこ とを試みた。歯肉炎罹患患者に Streptococcus mutans 生育阻害剂として注目を浴びている Dihydroguaiaretic acid を含有するメースエキス含有ガム, 卵白リゾチーム含有ガムおよび薬剤無添加のガム（コントロールガム）を 3 週間 使用させ, 臨床所見の変化, 副作用の有無について調べた。その結果, コントロールガム使用者には使用期間中, 臨 床所見の変化は認められなかったが,メースエキス含有ガム使用者および卵白リゾチーム含有ガム使用者の歯肉の炎

本論文の要旨は, 第 32 回春季日本歯周病学会総会（1989 年 5 月 13 日）において発表した。 
症状態, 出血に改善が見られた。また, メースエキス含有ガム使用者においてはプラークの減少がみられた。 索引用語 : メースエキス, 卵白リゾチーム, チューインガム, 歯肉炎

表 1 各種ガムの成分表（\%）

\section{緒言}

炎症性歯周疾患の主因子はプラークであることが疫学 的, 実験的に証明されている1 4)。このプラークを抑制す ることは治療上, 必要不可欠であり, 従来より歯ブラシ, 補助的清掃具, 洗口剤などが使用されている。しかし, これらを常時, 携帯させ, 毎食後, 使用させることは困 難である。過去に嗜好品として，広く親しまれているチ ユーインガムに, 酵素などを添加し, 補助的清掃法の一 助として用いる試みがいくつか報告されている ${ }^{5,6)}$ 。著 者らはより有効な薬用チューインガムを開発することを 目的として Streptococcus mutans 生育阻害剂として注目 されている Dihydroguaiaretic acid (以下 DHGA と略 する）を含有するメースエキスを添加したガムと，歯周 組織の炎症に過去の報告より効果の認められている卵白 リゾチーム含有ガム ${ }^{6}$ および 砂糖無添加のコントロール ガムを歯肉炎罹患患者に使用させ, 歯肉の炎症や口腔清 掃状態に対する臨床効果について比較検討し, 興味ある 結果を得たので報告する。

\section{材料および方法}

\section{1. 被験者および被験歯}

被験者は日本大学歯学部の学生で全身状態に異常がな く肉眼的に明らかに上下顎臼歯部歯肉に炎症の認められ る 22 歳から 30 歳までの男性 58 名, 女性 10 名, 計 68 名 を対象とし，被験歯は咬合関係に異常がなく，歯列不正 を有さず, 粗蝕および充填物, 補緅物のない上下顎臼歯 部とした。

\section{2. 各種ガムの成分}

今回の実験に使用したガムの組成を表 1 に示す。コン トロールガム（以下コントロールと略する）は 1 個あた り $5.0 \mathrm{~g}$ の重量で，その成分比は重量\%でガムベース $26.5 \%$, パラチノース $52.5 \%$, マルチトール $10.9 \%$, 還 元麦芽糖水诒 $8.2 \%$, 香料 $1.9 \%$ である。メースエキス 含有ガム（以下メースエキスと略する）はマルチトール を減らし $0.3 \%$ のメースエキスを添加したものである。 卵白リゾチーム含有ガム (以下リゾチームと略する) は, マルチトールを減らし $0.1 \%$ の卵白リゾチームを添加し たものである。

\begin{tabular}{l|ccc}
\hline & コントロール & メースエキス & リゾチーム \\
\hline ガムベース & 26.5 & 26.5 & 26.5 \\
パラチノース & 52.5 & 52.5 & 52.5 \\
マルチトール & 10.9 & 10.6 & 9.9 \\
還元麦芽糖水飴 & 8.2 & 8.2 & 8.2 \\
香料 & 1.9 & 1.9 & 1.9 \\
卵白リゾチーム & - & - & 1.0 \\
メースエキス & - & 0.3 & - \\
\hline
\end{tabular}

\section{3. 実験方法}

試験スケジュールは以下のとおりである。6 8 名の対象 者を無作為に, コントロール使用者 18 名, メースエキス 使用者 25 名，リゾチーム使用者 25 名にふりわけた。実 験開始日（以下 0 週目とする）に, 各個人の臨床診査を 行い, ガムを与え, 3 週間, 1 日 3 回, 毎食後, 各々の ガムを 1 個ずつ 3 分間以上，嚙むように指導した。各人 の日常の食物の採取, 口腔清掃法に関しては, 特に指導 は行わなかった。 1 週間後, 2 週間後, 3 週間後に来院 させ, 計 4 回の臨床診査を行った。

\section{4. 臨床診査項目}

歯肉炎の広がりの程度は Massler \& Schour の PMA index (以下 PMA と略する) に準じた。すなわち, 上 下顎とも第 1 小目歯から第 2 大臼歯までの歯間歯肉, 辺 縁歯肉, 付着歯肉のそれぞれの頓側部位での炎症の存在 の有無を 0 あるいは 1 の数值で表現し, 全体の合計点数 を各個人の PMA とした。

歯肉炎の程度は Löe \& Silness の Gingival index (以 下 GI と略する) を用いた。すなわち，0を健康な状態 とし，1 を辺縁歯肉にわずかに発赤, 腫脹が認められ, 歯肉溝には滲出液の浸潤があり, プロービング時の出血 が認められない状態，2 2 をプロービングにより出血が認 められる状態とし，3 を自然出血傾向などが認められる 状態として，1歯につき頓側面, 舌側面, 近心面, 遠心 面を診査し, 全歯の平均值を算定し, 各個人の GI とし た。

歯肉の出血は Ainamo \& Bay の Gingival bleeding index (以下 GBI と略する) に準じた。1歯あたり煩舌 側とも中央, 近心, 遠心計 6 点を注意深くプロービング し, 約 10 秒後に歯周ポケットから出血が認められた 部 位の合計值が被験部位の何％であるかを算定し，各個人 
表 2 臨床診査結果

\begin{tabular}{|c|c|c|c|c|c|}
\hline ガム & 時期 $^{\text {項目 }}$ & PMA & GI & GBI (\%) & PSS \\
\hline \multirow{4}{*}{$\begin{array}{l}コ \\
ン \\
1 \\
\square \\
1 \\
ル\end{array}$} & 0 週目 & $30.06 \pm 4.11$ & $1.34 \pm 0.24$ & $24.44 \pm 16.67$ & $1.71 \pm 0.76$ \\
\hline & 1 逞目 & $30.00 \pm 4.67$ & $1.28 \pm 0.21$ & $22.90 \pm 15.71$ & $1.81 \pm 0.65$ \\
\hline & 2 週目 & $29.67 \pm 4.04$ & $1.26 \pm 0.19$ & $20.03 \pm 12.92$ & $1.81 \pm 0.69$ \\
\hline & 3 週目 & $28.83 \pm 4.09$ & $1.32 \pm 0.24$ & $24.62 \pm 18.67$ & $1.78 \pm 0.85$ \\
\hline \multirow{4}{*}{$\begin{array}{l}x \\
1 \\
\text { ス } \\
\text { I } \\
\neq \\
\text { ス }\end{array}$} & 0 週目 & $32.12 \pm 9.70$ & $1.33 \pm 0.25$ & $26.20 \pm 18.14$ & $1.95 \pm 0.63$ \\
\hline & 1 週目 & $15.80 \pm 5.67$ & $0.98 \pm 0.30$ & $23.30 \pm 12.50$ & $1.81 \pm 0.78$ \\
\hline & 2 週目 & $3.20 \pm 2.96$ & $0.66 \pm 0.37$ & $21.73 \pm 14.12$ & $1.48 \pm 0.69$ \\
\hline & 3 週目 & $1.84 \pm 1.75$ & $0.54 \pm 0.32$ & $18.06 \pm 11.95$ & $1.40 \pm 0.75$ \\
\hline \multirow{4}{*}{$\begin{array}{l}\text { リ } \\
\text { ゾ } \\
\text { チ } \\
! \\
厶\end{array}$} & 0 週目 & $31.76 \pm 4.67$ & $1.36 \pm 0.18$ & $28.28 \pm 16.83$ & $1.64 \pm 0.92$ \\
\hline & 1週目 & $10.67 \pm 6.94$ & $0.83 \pm 0.39$ & $23.38 \pm 16.71$ & $1.81 \pm 0.82$ \\
\hline & 2 週目 & $3.84 \pm 3.67$ & $0.71 \pm 0.42$ & $21.59 \pm 14.42$ & $1.84 \pm 0.84$ \\
\hline & 3 週目 & $3.40 \pm 3.48$ & $0.65 \pm 0.33$ & $19.55 \pm 10.32$ & $1.64 \pm 0.68$ \\
\hline
\end{tabular}

Mean \pm SD

表 3 各観察時期における各種ガム間の PMA の比較

\begin{tabular}{c|c|c|c}
\hline & $\begin{array}{l}\text { コントロールー } \\
\text { リゾチーム }\end{array}$ & $\begin{array}{c}\text { コントロール- } \\
\text { メースエキス }\end{array}$ & $\begin{array}{c}\text { リゾチームー } \\
\text { メースエキス }\end{array}$ \\
\hline 0 週目 & $*$ & $\mathrm{NS}$ & $\mathrm{NS}$ \\
1 週目 & $* *$ & $* *$ & $* *$ \\
2 週目 & $* *$ & $* *$ & $\mathrm{NS}$ \\
3 週目 & $* *$ & $* *$ & $\mathrm{NS}$ \\
\hline
\end{tabular}

NS : Not Significant

$* *: \mathrm{P}<0.01 \quad *: \mathrm{P}<0.05$

の GBI とした。

口腔清掃状態は Quigly \& Hein の Plaque scoring system (以下 PSS と略する) を改良して用いた。すな わち, 各被験歯の煩舌側面を観察し, 歯面にプラークの 付着のない場合を 0 , 歯頸部に点状にプラークが付着し ている場合を 1 , 線状に付着している場合を 2 , 歯面の歯 冠側 $1 / 3$ まで付着している場合を $3,2 / 3$ までを $4,2 / 3$ 以 上を 5 とした。各被験歯面の点数を合計し, 被験歯面数 で割り各個人の PSS とした。なお PMA, GI, GBI, PSS, 4 つの観察事項に関しては試験期閒中, 同一の験者が観 察し続けた。また, 副作用に関しては, 各観察時期に, 視診にて, 歯, 舌の着色, 口腔粘膜の糜爛を診査し, ガ ムを嚙んだ際の不快味, 口腔灼熱感などは問診を行っ た。

\section{5. 統 計}

各種ガム間の各観察時期における PMA, GBI の比較 および各種ガムの各観察時期間の PMA, GBI の比較は $\chi^{2}$ 検定を, 各種ガム閒の各観察時期における GI, PSS の比較は Mann-Whitney のU検定を, 各種ガムの各観 察時期間の GI, PSS の比較は Wilcoxon の符号順位検 定を行った。

\section{結 果}

\section{1. 臨床所見の変化}

被験者の試験期閒中の各観察項目の平均值の変化を表 2 に示した。コントロールは試験期間中，4つの観察項 目に特に変化はみられなかった。メースエキスは PMA， GI は, 1 週目から低下し, GBI も低下寸る傾向が認めら れ, 3 週目まで，その值は低下し続けた。また PSS は， 試験期間を通じて低下する傾向が認められた。リゾチー ムは 1 週目から, PMA，GI は低下し GBI は低下する傾 向が認められ，その後，3つの観察項目とも 3 週目まで 低下した。PSS に関しては 3 週間を通じてほとんど変化 は認められなかった。

以上 3 種類のガムによる臨床所見は初診時は， 3 種類 間でほとんど差は認められなかったが，コントロールは 試験期間を通じて, 各観察項目の值は変化せず, リゾチ ーム,メースエキスは, PMA, GI, GBI は低下し，PSS に関しては, リゾチームは変化がなかったが，メースエ キスは試験期間を通じて，低下する傾向が認められた。

\section{2. 各観察時期における各種ガム間の比較}

各観察時期における各種ガム間の PMA の比較を表 3 に示した。0週目において, PMA は，コントロールとリ ゾチーム間で, 統計学的有意差を認めたが, その他は認 
表 4 各観察時期における各種ガム間の GI の比較

\begin{tabular}{c|c|c|c}
\hline & $\begin{array}{c}\text { コントロール- } \\
\text { リゾチーム }\end{array}$ & $\begin{array}{c}\text { コントロールー } \\
\text { メースエキス }\end{array}$ & $\begin{array}{c}\text { リゾチームー } \\
\text { メースエキス }\end{array}$ \\
\hline 0 週目 & $\mathrm{NS}$ & $\mathrm{NS}$ & $\mathrm{NS}$ \\
1 週目 & $* *$ & $* *$ & $*$ \\
2 週目 & $* *$ & $* *$ & $\mathrm{NS}$ \\
3 週目 & $* *$ & $* *$ & $\mathrm{NS}$ \\
\hline
\end{tabular}

NS : Not Significant

$* *: \mathrm{P}<0.01 *: \mathrm{P}<0.05$

表 5 各観察時期における各種ガム間の GBI の比較

\begin{tabular}{c|c|c|c}
\hline & $\begin{array}{c}\text { コントロール- } \\
\text { リゾチーム }\end{array}$ & $\begin{array}{c}\text { コントロール } \\
\text { メースエキス }\end{array}$ & $\begin{array}{c}\text { リゾチームー } \\
\text { メースエキス }\end{array}$ \\
\hline 0 週目 & $\mathrm{NS}$ & $\mathrm{NS}$ & $\mathrm{NS}$ \\
1 週目 & $\mathrm{NS}$ & $\mathrm{NS}$ & $\mathrm{NS}$ \\
2 週目 & $\mathrm{NS}$ & $\mathrm{NS}$ & $\mathrm{NS}$ \\
3 週目 & $* *$ & $* *$ & $\mathrm{NS}$ \\
\hline
\end{tabular}

NS : Not Significant

$$
\text { **: } \mathrm{P}<0.01 *: \mathrm{P}<0.05
$$

表 6 各観察時期における各種ガム間の PSS の比較

\begin{tabular}{c|c|c|c}
\hline & $\begin{array}{c}\text { コントロール- } \\
\text { リゾチーム }\end{array}$ & $\begin{array}{c}\text { コントロール- } \\
\text { メースエキス }\end{array}$ & $\begin{array}{c}\text { リゾチーム- } \\
\text { メースエキス }\end{array}$ \\
\hline 0 週目 & $\mathrm{NS}$ & $\mathrm{NS}$ & $\mathrm{NS}$ \\
1 週目 & $\mathrm{NS}$ & $\mathrm{NS}$ & $\mathrm{NS}$ \\
2 週目 & $\mathrm{NS}$ & $\mathrm{NS}$ & $\mathrm{NS}$ \\
3 週目 & $\mathrm{NS}$ & $\mathrm{NS}$ & $\mathrm{NS}$ \\
\hline
\end{tabular}

NS : Not Significant

$* *: \mathrm{P}<0.01 *: \mathrm{P}<0.05$

められなかった。1 週目において,メースエキス,リゾ チームともコントロールとの間に統計学的有 意差を認 め, 2 週目, 3 週目も，その傾向は認められた。リゾチー ム, メースエキス閒は 1 週目は統計学的有意差を認めた が, 2, 3 週目では認められなかった。GI の比較は表 4 に 示した。 0 週目で各種ガム間に統計学的有意差は認めら れなかった。1 週目においてコントロールと他のガムに は統計学的有意差を認め, この傾向は 3 週目まで続い た。2 週目, 3 週目でリゾチームとメースエキス間に統計 学的有意差は認められなかった。GBI の比較は表 5 に示 した。コントロールと比較し，メースエキス，リゾチー ムとも $0 ， 1 ， 2$ 週目では統計学的有意差は認められなか ったが， 3 週目において，統計学的有意差を認めた。し
表 7 各種ガムの各観察時期間の PMA の比較

\begin{tabular}{|c|c|c|c|}
\hline & コントロール & メースエキス & リゾチーム \\
\hline 0 逞- 1 週 & NS & $* *$ & $* *$ \\
\hline () 逛-2 萿 & NS & $* *$ & $* *$ \\
\hline 0 週-3 3 洁 & NS & $* *$ & $* *$ \\
\hline 1 週- - 2 洁 & NS & $* *$ & $* *$ \\
\hline 1 週 -3 週 & NS & $* *$ & $* *$ \\
\hline 2 造一 3 週 & NS & $* *$ & NS \\
\hline
\end{tabular}

NS : Not Significant

$* *: \mathrm{P}<0.01 \quad *: \mathrm{P}<0.05$

表 8 各種ガムの各観察時期間の GI の比較

\begin{tabular}{c|c|c|c}
\hline & コントロール & メースエキス & リゾチーム \\
\hline 0 週- 1 週 & $\mathrm{NS}$ & $* *$ & $* *$ \\
0 週- 2 週 & $*$ & $* *$ & $* *$ \\
0 週- 3 週 & $\mathrm{NS}$ & $* *$ & $* *$ \\
1 週 -2 週 & $\mathrm{NS}$ & $* *$ & $*$ \\
1 週- 3 週 & $\mathrm{NS}$ & $* *$ & $*$ \\
2 週- 3 週 & $\mathrm{NS}$ & $*$ & $\mathrm{NS}$ \\
\hline
\end{tabular}

NS : Not Significant

$* *: \mathrm{P}<0.01 \quad *: \mathrm{P}<0.05$

表 9 各種ガムの各観察時期間の GBI の比較

\begin{tabular}{|c|c|c|c|}
\hline & コントロール & メースエキス & リゾチーム \\
\hline 0 週- 1 週 & NS & $*$ & $* *$ \\
\hline 0 週一 2 週 & $*$ & $* *$ & $* *$ \\
\hline 0 週-3 萿 & NS & $* *$ & $* *$ \\
\hline 1 週- 2 速 & NS & NS & NS \\
\hline 1 速一3 速 & NS & NS & NS \\
\hline 2 週一 3 速 & $*$ & $* *$ & NS \\
\hline
\end{tabular}

NS : Not Significant

$* *: \mathrm{P}<0.01 *: \mathrm{P}<0.05$

かしメースエキス, リゾチーム間では統計学的有意差は 認められなかった。PSS の比較は表 6 に示した。すべて 統計学的有意差は認められなかった。

\section{3. 各種ガムの各観察時期間の比較}

各種ガムの各観察時期間に打ける PMA の比較は表 7 に示した。コントロールは, 観察期間中, 統計学的有意 差は認められなかった。メースエキス，リゾチームは， 0 週目と $1,2,3$ 週目の比較において, すべて統計学的有 意差を認めた。GI の比較を表 8 に示した。コントロー ルは 0 週目と比較し， 2 週目は統計学的有意差が認めら れたが, その他では統計学的有意差が認められなかっ た。メースエキスとリゾチームに関しては， 0 週目と 1 , 2,3 週目の間に統計学的有意差が認められた。 
表 10 各種ガムの各観察時期間の PSS の比較

\begin{tabular}{l|c|c|c}
\hline & コントロール & メースエキス & リゾチーム \\
\hline 0 週一 1 週 & $\mathrm{NS}$ & $\mathrm{NS}$ & $\mathrm{NS}$ \\
0 週-2 週 & $\mathrm{NS}$ & $* *$ & $\mathrm{NS}$ \\
0 週-3 週 & $\mathrm{NS}$ & $* *$ & $\mathrm{NS}$ \\
1 週- 2 週 & $\mathrm{NS}$ & $* *$ & $\mathrm{NS}$ \\
1 週-3 週 & $\mathrm{NS}$ & $* *$ & $\mathrm{NS}$ \\
2 週-3 週 & $\mathrm{NS}$ & $\mathrm{NS}$ & $\mathrm{NS}$ \\
\hline
\end{tabular}

NS : Not Significant

$* *: \mathrm{P}<0.01 \quad *: \mathrm{P}<0.05$

GBI の比較を表 9 に示した。コントロールは 0 週目と 2 週目, 2 週目と 3 週目に, 統計学的有意差を認めたが, その他は認められなかった。メースエキス, リゾチーム に関しては 0 週目と比較し, $1,2,3$ 週目とも統計学的有 意差を認めた。PSS の比較は表 10 に示した。コントロ ール，リゾチームとも，各週間に変化はなかったが，0 週目と比較しメースエキスでは 2,3 週目に統計学的有 意差が認められた。

\section{4. 安 全 性}

副作用については，各種ガムとも，各観察時期におい て歯, 舌の着色, 口腔粘膜の糜爛, ガムを嚙んだ際の不 快味, 口腔灼熱感などは認められなかった。

\section{考察}

近年, 各人の口腔衛生に関する知識が高まり, 洗口

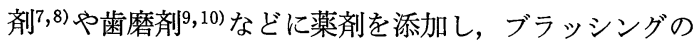
補助として利用し歯周治療あるいは口臭予防の試みがな されている。しかし，これらを，効果的に使用するには 定期的に，また習慣的に使用することが必要であるが， 現実として日常生活で携帯し定期使用することは困難な 場合が多い。そこで著者らは，嗜好品として広く親しま れ，携帯にも便利なチューインガムにニクズク科の常緑 樹である Myristica fragrans Houtt の種皮より有機溶媒 により抽出され, 古来より抗酸化作用, 抗菌作用を有す るとされ，また味覚的な面でスパイス的効果があり甘味 を助長し嗜好性もあることから食肉加工や製菓, ベーカ リー類, ソース，少ャップ，カレーなどに使用されて いるメースエキス ${ }^{11,12)}$ を含有させたガムと歯肉の炎症に 効果のあることが報告されている卵白リゾチーム含有ガ ムおよび薬剤を添加していないガムと比較しその臨床効 果について検討を行った。近年，メースエキス中の含有 物質のフェノール誘導体である DHGA は Streptococcus mutans に対し抗菌作用を持つことが in vitro において 証明されている13)。今回の試験ではメースエキス使用者 は PSS が 2, 3 週目に統計学的に有意に低下した。これ は，前述のメースエキスの抗菌作用によるものと考えら れる。しかし，炎症に関しては Löe ら ${ }^{3)}$ の報告のように プラーク量の軽減に伴って炎症が軽減するよりも，今回 の試験では 2,3 週目に見られたプラークの量的変化の 前に 1 週目で, PMA, GI, GBI が統計学的に有意に低下 している。メースエキスには，歯肉の炎症状態に関係す ると考えられている Bacteroides gingivalis, Bacteroides melaninogenicus, Actinomyces naeslundii, Actinomyces israelii, Actinomyces viscosus などの細菌に対する抗菌 作用が予備実験にて観察されており，メースエキスがプ ラーク中のこれらの細菌に対して抗菌作用を呈すること により, Loesche ら ${ }^{14)}$ が報告しているように, プラーク の質的な変化が生じ, それに伴いプラークの量的な変化 の前に，歯肉の炎症に対して効果を示したことが考えら れる。また,メースエキスの特性のひとつとして抗酸化 作用 ${ }^{12)}$ があげられるが，その主役となる物質は Myristiphenon というフェノール誘導体であることが証明され ている ${ }^{11)}$ 。近年，フェノール誘導体はその $\mathrm{OH}$ 基が炎症 に関与すると言われている活性酸素を除去する作用を有 することより，その抗炎症作用が注目されている。また ユージノールなどの $\mathrm{OH}$ 基を有するフェノール誘導体は in vitro で好中球の遊走能に対して抑制的に働くという 報告 $\left.{ }^{15}, 16\right)$ がある。さらに抗酸化作用を有し，その歯肉中 の量が歯肉の炎症状態に関係があることが報告されてい る $\alpha$-トコフェロール ${ }^{17)}$ と比較し，メースエキスは強 い抗酸化作用を有するという報告 ${ }^{12)}$ もる。そこで, メ ースエキスの抗酸化作用により活性酸素を除去し, 歯肉 の炎症状態が軽減したことが考えられる。以上，メース エキス使用者の PMA, GI, GBI の低下はプラークの 質的な変化による間接的な作用と抗酸化作用による歯肉 に対する直接的な作用により生じたものと考えられる。 一方，リゾチーム使用者に関しては，プラークの量的変 化なしに 1 週目で PMA, GI, GBI ともに軽減している。 卵白リゾチームは鶏卵の卯白中に大量に含まれ，薬理作 用として出血抑制作用，抗炎症作用，瘢痕形成作用など が報告されている酵素18)で，歯科の分野では，その抗炎 症作用が注目され，歯磨剂 ${ }^{9,10)}$ やチューインガム ${ }^{6)} に$ 含 有させ局所応用したり，錠剤 ${ }^{19,20)}$ に含有させ全身応用 させ，歯肉炎症を軽減させる効果が報告されている。 今回の卵白リゾチームは過去に当教室にて行ったチュー インガムの臨床診査所見の変化を観察した試験の歯肉の 
炎症，出血を抑制するが，口腔清掃状態には恋化を示さ なかった報告6) と一致する。そこで, リゾチーム使用者 に関しては，その抗炎症作用および出血抑制作用によ り, PMA, GI, GBI が低下したものと考えられる。今 回，炎症の面でメースエキスは卵白リゾチームと同様な 所見を示したが，卵白リゾチームは口腔清掃状態には影 響を及ぼさないこと, 錠剤として使用した場合, 胃重 感, 発疹, 口渴, 嘔吐等 ${ }^{19,20)}$ の副作用が見られたこと, 卵白リゾチームの至適 $\mathrm{pH}$ は 6.0 から 7.0 であり効果に 関して口腔内の環境により影響をうけることが考えられ ることからメースエキスはより臨床的に有用であると考 えられる。今後，メースエキスに関しては長期使用の観 察およびプラークに対する効果, 口腔内の停滞能などに ついてさらに検討を加える必要性が考えられる。

\section{結論}

歯周疾患の予防および治療に使用する目的で歯肉炎罹 患患者にメースエキス含有ガムを使用させ，卵白リゾチ 一ム含有ガムおよび薬剤無添加のガムと比較し, 以下の 結論を得た。

1.メースエキス含有ガムは卵白リゾチーム含有ガム 同様 PMA, GI, GBI を低下させた。

2.メースエキス含有ガムは試験期間中, PSS を低下 させる傾向が認められた。

3. 各種ガムとも副作用はなかった。

\section{謝 辞}

チューインガムの提供を受けた株式会社ロッテ中央研究所に 感謝致します。

\section{文献}

1) Socransky, S.S. : Microbiology of periodontal disease-present status and future considerations. J. Periodontol., 48 : 497-504, 1977.

2) Newman, H.N. : Update on plaque and periodontal disease. J. Clin. Periodontol., 7 : 251258, 1980.

3) Löe, H., Theilade, E. and Jensen, S.B. : Experimental gingivitis in man. J. Periodontol., $36:$ 177-187, 1965.

4) Theilade, E., Wright, W.H., Jensen, S.B. and Löe, H. : Experiodontal gingivitis in man. II A
Longitudinal clinical and bacteriological investigation. J. Periodont. Res., 1 : 1-13, 1966.

5）村井正大，五十嵐昭夫，伊藤公一，金森誠二，大 谷一好, 佐藤吉永: Dextranase 含有チューイン ガム使用によるヒトの歯苔抑制効果について．日 歯周誌, $17: 74-79,1975$.

6）村井正大，伊藤公一，真野一，片山一郎，渡辺 和仁，折笠広樹，高野雅行 : 辺縁性歯周炎に対す るリゾチーム含有チューインガムの使用成績につ いて. 日歯周誌, $19: 239-243,1977$.

7）吉沼直人, 音琴淳一, 藤川謙次, 佐野裕士, 伊藤公 一，村井正大：Viadent ${ }^{\circledR}$ および Chlorhexidine のプラーク抑制効果. 日歯 周 誌, $28: 235-243$, 1986.

8) Flötra, L., Gjermo, P., Rölla, G. and Waerhaug, J. : A 4-month study on the effect of chlorhexidine mouthwashes on 50 soldiers. Scand. J. Dent. Res., 80 : 10-17, 1972.

9）前田勝正，鎖守信弘，原 宣興，古川猛士，畠山 民子，宮武祥子，岩本恭行，長嶺尚子，鄭 有仁， 橋口 勇, 赤峰昭文, 青野正男 : 辺縁性歯周炎に おける塩化リゾチーム含有歯磨剤の臨床効果につ いて. 日歯周誌, $28: 758-766,1986$.

10）太田紀雄, 秋田有一, 平林秀俊 : 歯周疾患に対す る塩化リゾチーム含有歯磨剤 “デンテクブラッシ ングクリーム”の臨床効果. 日歯周誌， $25: 254$ 264,1983

11）武政三男 : スパイス百科事典, 第 1 版, 三琇書房, 東京, 1981，243-250。

12）中谷延二，菊崎奉枝：ナツメグ，メースの抗菌. 抗酸化作用. フードケミカル，2:70-74，1988.

13) Hattori, M., Hada, S.H., Watahiki, A., Ihara, H., Shu, Y.Z., Kakiuchi, N., Mizuno, T. and Namba, T. : Studies on caries prevention by traditional medicines. $\mathrm{X}$. Antibacterial action of phenolic components from Mace against Streptococcus mutans. Chem. Pharm. Bull., 34 : 3885-3893, 1986.

14) Loesche, W.J. and Syed, S.A. : Bacteriology of human experimental gingivitis : Effect of plaque and gingivitis score. Infect. and Immun. $21: 830-839,1978$.

15）横山智則：フェノールおよびその誘導体の白血球 遊走反応を指標とした抗炎症作用について，歯基 
礎誌, 27 : 1153-1168, 1985.

16) Azuma, Y., Ozawa, N., Ueda, Y. and Takagi, N. : Pharmacological studies on the antiinflammatory action of phenolic componuds. J. Dent. Res., 65 : 53-56, 1986.

17）藤川謙次：辺縁性歯周炎罹患歯肉 中 $\sigma \alpha$-tocopherol 量の変動について. 日歯周 誌, $25: 178-$ 184, 1983.

18）松岡芳隆 : 卵白リゾチームの化学とその利用. 栄
養と食料, $24: 311-316,1971$.

19）松江一郎, 鈴木文雄, 鈍木康司 : リゾチーム経口 投与による歯周疾患患者の唾液リゾチーム活性の 消長について. 日歯周誌， $10: 5-10 ， 1969$.

20）恵比須繁之, 岡田 宏, 今田久夫, 山岡 昭, 宮 下 元, 長谷川紘司, 泉澤勝憲, 小田 茂, 北村 滋, 木下四郎, 三宮慶邦, 河西一秀 : 歯周疾患に 対するレフトーゼ $30 \mathrm{mg}$ 錠の臨床効果. 日歯周 誌, $25: 242-255,1983$. 